\title{
Lara Pagani
}

\section{Through the warping glass}

\section{A reconsideration on Venetus A subscriptions and the birth of scholiography*}

\begin{abstract}
This article reflects on the subscriptions which, in ms. Venezia, Biblioteca Nazionale Marciana, gr. 454 (coll. 822) of the Iliad, mention the ancient sources that were compiled in the apparatus of the scholia, concluding that they might actually not refer at all to the positioning of the exegetic annotations in the margins of the manuscript: hence, they prove not to be conclusive for dating the origins of scholiography.
\end{abstract}

Keywords: Greek scholia, manuscript subscriptions, ms. Venetus A.

DOI 10.1515/tc-2014-0005

Considerable debate has focused on the most plausible dating of the time period that saw the birth of the scholiographic corpora documented by the medieval tradition. Some scholars believe that the origins of scholiography can be traced as far back as Late Antiquity, while others prefer a more cautious estimation, suggesting the mid-Byzantine age ${ }^{1}$. It should be clarified here that scholiography is to be understood as a practice of systematic and programmatic compilation from more than one exegetic source, resulting in a product methodically arranged in the margins of the codex containing the literary text that forms the subject of the commentary ${ }^{2}$. Thus it is a phenomenon distinct from the marginal annotations found in numerous Late Antique codices, for which, despite a few controversial cases, it has so far not been possible to prove conclusively that they were

\footnotetext{
* This research has been performed within the framework of the project "Omero, Esiodo, Pindaro, Eschilo: forme e trasmissione dell'esegesi antica", financed in the program FIRB - "Futuro in Ricerca” 2012 by the Italian Ministero dell'Istruzione, dell'Università, della Ricerca.

1 A general overview was recently presented and discussed in a wide-ranging study by Fausto Montana (2011a). Cf. also Introduction, this volume.

2 Cf. Montana 2011a, 107: "We will define a corpus of scholia as an exegetic editio variorum, designed to be made up in an orderly way alongside or around the text commented upon”.
}

Lara Pagani: University of Genoa, E-Mail: lara.pagani@unige.it. 
the fruit of a conscious blending of different sources ${ }^{3}$. The distinction is by no means trivial and does not concern a merely terminological problem (scholia / marginalia). Rather, it involves a crucial aspect: the practice of jotting down a few philological-exegetic notes at the side of the literary text, in the margins of the codex, such notes being taken from a commentary that was at hand, can by no means be seen as having the same cultural relevance and the same significance in terms of the aim of preserving and transmitting the past as does the methodical and large-scale operation of selecting and agglutinating multiple and widely varying materials, for the specific purpose - and this is the only element the two types of operation have in common - of setting them alongside the text that is the object of study. The use of simple jottings may well have suggested their potential as tools for material realization of the more extensive operation, but they cannot be regarded as the same thing.

For scholiography taken in this comprehensive and more significant sense, there exists no positive and certain documentation prior to the medieval era ${ }^{4}$. However, numerous attempts have been made, on a deductive basis, to find indirect evidence of this phenomenon even in the Late Antique age, adducing a great range of arguments such as parallels with the biblical catenae and with the scholiography of the Latin world, paleographic investigation into the development of small-sized handwriting as well as research on the subscriptions which, in some medieval manuscripts, record the ancient sources that were compiled in the apparatus of scholia; moreover, the eventuality that independent commentaries on codex may have survived up to the dawn of the Byzantine era is generally viewed with skepticism.

The aim of my contribution is to reflect specifically on the subscriptions, in particular those present in the ms. Venezia, Biblioteca Nazionale Marciana, gr. 454 (coll. 822), the celebrated Venetus A witness of the Iliad ${ }^{5}$. This manuscript has an interesting feature in common with some other medieval codices that preserve ancient literary works equipped with scholiographic corpora (in addition to the Iliad, some plays of Aristophanes and Euripides, the Argonautics of Apollonius Rhodius): the feature in question is the peculiarity of having colophons that

3 Discussion in Montana 2011a, 128-150.

4 Montana 2011a, 161. This is also recognized by some scholars who support the argument of a Late Antique origin of scholiograhy: cf. e.g. Cavallo/Del Corso 2012, 57 and 61 and, exclusively for Homer, Pontani 2005, 98-99.

5 I share Montana's hope (2011a, 156-161; cf. already 2006, 19-20) of a shift in direction, moving away from a general and "transverse" approach - which, however, did yield significant fruits in the past - in favor of an investigation into the specific exegetic traditions, so as to award due consideration to the peculiarities of each tradition. 
name the auctoritates from which the mass of exegetic material accompanying the text has been derived ${ }^{6}$. In Venetus $A$, at the bottom of every book of the Iliad (with just a few exceptions, to be mentioned below) we find a formulation that presents small variants here and there and/or minor omissions and which, in its most complete and correct form, runs as follows:

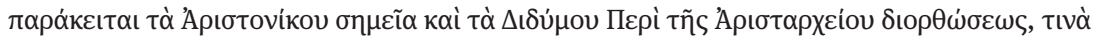

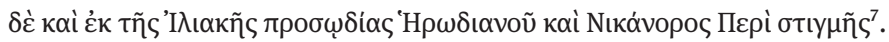

This formulation thus lists the works providing the source of the selected annotations that make up the exegetic apparatus represented by the scholia (or rather, part of this apparatus, as will be seen below): Aristonicus' On signs ${ }^{8}$, Didymus' On the diorthosis of Aristarchus, Herodian's Prosody of the Iliad and Nicanor's On Punctuation. Here, the verb that describes this operation is $\pi \alpha \rho \alpha \dot{\kappa \varepsilon} \tau \alpha \mathrm{l}$, while in other cases among the traditions mentioned above there appears the equivalent $\pi \alpha \rho \alpha y \varepsilon ́ \gamma \rho \alpha \pi \tau \alpha$. The most typical present-day translation, often supplied without any apparent need to discuss the issue, is given as "are placed alongside

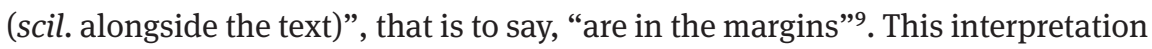

6 Overview in Cavallo 1992, 99-100 (= 2002, 181-182); Cavallo 2000, 57-58; Montana 2010, 192; Montana, 2011a, 151; Montana, this volume.

7 This version can be read, for instance, at the end of book 2 (f. 41v). The addition of $\mu \varepsilon \tau \grave{\alpha}$

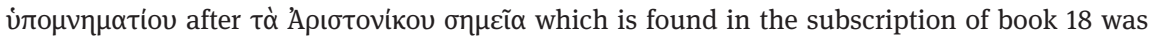
identified by Lehrs $1882^{3}, 2$ as a modification introduced at a later stage, subsequent to the first redaction of the colophons, while Erbse 1975, 571 justified this expression by surmising that the "medii aevi homunculus" to whom he attributed the redaction of the subscriptions of Venetus A had poor ability to choose the right words (on this, cf. immediately infra, in the text).

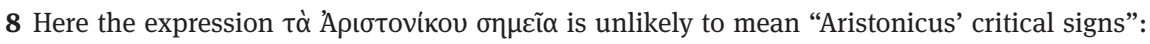
rather, it should more properly be explained as a brachylogic formulation to indicate the title

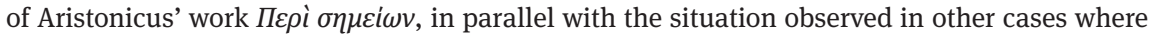

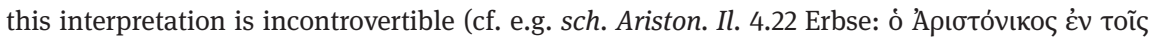

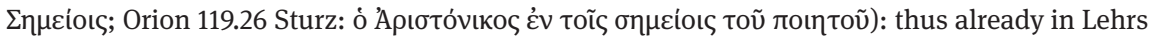
18823 , 1-2, Erbse 1969, XI-XII with n. 1, XV and, more recently, van Thiel 2000a, 11-12 ("sie [scil. the subscriptions] nennen offenbar diejenigen Kommentare, die einen bestimmten Namen und Titel trugen”: cf. van Thiel 2014, 1.27); Dickey 2007, 19; Blackwell/Dué 2009, 7; Braswell 2013, 46. A different opinion is put forward by Mazzucchi, in this volume, who apparently uses the expres-

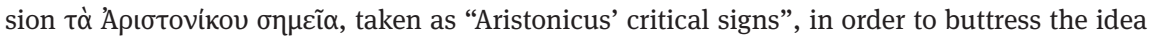
that here $\pi \alpha \rho \alpha \dot{\kappa \varepsilon} \iota \tau \alpha ı$ means "are in the margins": if the subscription speaks of critical signs, then

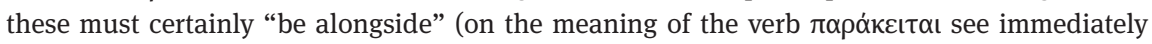
infra in the text). Seemingly this same opinion is also shared by Nagy 2004, 6-7, who translates: "placed in the margins are the signs of Aristonicus etc.".

9 Cf. e.g. van Thiel 2000a, 11-12; Nagy 2004, 6-7 (also cited by Bird 2009, 90); Blackwell/Dué 2009, 7; Hecquet 2009, 69; Dickey 2007, 19; Braswell 2013, 46; van Thiel 2014, 1.27. 
is based on the spatial acceptation of the preverb $\pi \alpha \rho \alpha$, “at”, "near”, "alongside”, and it appears quite natural and spontaneous to anyone who, like us, happens to read the verb at the foot of a page in a manuscript which effectively does have the exegetic material "in the margins".

A number of elements have led to the assumption that the colophons in question date back to Late Antiquity, more precisely to a period between the end of the $\mathrm{IV}^{\text {th }}$ and the beginning of the VII ${ }^{\text {th }}$ century ${ }^{10}$. This period seems to be suggested, according to Guglielmo Cavallo, by "l'uso stesso di testimoniare certe operazioni filologiche in sottoscrizioni" (as shown above all by the tradition of the Latin authors $)^{11}$, and the recurrence of the subscription at the end of every book: this phenomenon is seen as a resumption, which is typical of the most ancient codices, of a practice intrinsic to the exemplars still written on rolls, where the paratextual elements had to be specified on every textual or book unit. Moreover, in Venetus A the subscription is lacking not only for book 17 - whose ending was written on one of the sheets that went lost and were substituted by more recent ones, on which the exegetic apparatus was not copied (f. 238) $)^{12}$ - but also, and most significantly, for the last book: here the absence of the subscription has been interpreted as a symptom of a Late Antique model whose last sheet had, over the centuries, deteriorated or become illegible due to damage to the materials ${ }^{13}$. Finally, further support for this view is provided by a technical-formal component such as the frieze that forms a frame surrounding the colophons at the end of several Iliadic books (but also the colophon of Aristophanes' Clouds), which Cavallo sees as replicating decorative modules characteristic of Late Antique exemplars ${ }^{14}$.

Once this version concerning the earliest origin of the subscriptions has been established, the next step is to deduce the Late Antique chronology of the operation mentioned in the subscriptions. This is perfectly legitimate. The problem resides in determining what was actually involved in the operation. And to gain insight into the nature of the operation, it is crucial to understand the meaning of

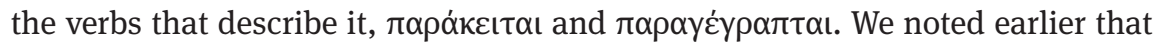
it is quite instinctive to propose the translation "they are placed / written in the margins", which would lead us precisely into the perspective of scholiographic practice in the most significant sense. However, since we are using a deductive

10 Cavallo 1992, 100-102 (= 2002, 182-184); Cavallo/Del Corso 2012, 58-60.

11 "The very habit of providing evidence of certain philological operations in subscriptions": Cavallo 1992, 100 (= 2002, 182).

12 Cf. Erbse 1969, XIV; West 2001a, 140; Hecquet 2009, 64. Mioni 1976, 192-193 attributed these restorations in Venetus A to Bessarion.

13 Cavallo/Del Corso 2012, 59.

14 Cavallo 1992, 103 (= 2002, 186). 
procedure to argue indirectly in favor of the existence of something for which we have no positive witness ${ }^{15}$, we need to be sure that the elements on which we are basing our conclusion could not admit of another explanation as well. In other words, this kind of indirect argument must bear the burden of proof and anyone who uses it must carefully check whether the premises on which it is based lead to that one and only specific result.

Now, it has been demonstrated that there are cases where the two verbs in question, and likewise the equivalent $\pi \alpha \rho \alpha \tau i \theta \varepsilon \sigma \theta \alpha$, do not occur in the acceptation of "being alongside", as this acceptation cannot be reconciled with the setting in which they are found. Rather, the relevant contexts strongly orients them towards the meaning "be quoted / cited / extracted", in relation to the figurative sense of the preverb ${ }^{16}$ and without any mention of a position "alongside (scil. the text)", hence "in the margins"17. This means that the verb which, in our subscriptions, expresses an essential aspect without which one cannot speak of scholiography - i.e. the condition of being placed alongside the text - can actually also have a different meaning. Therefore, it becomes indispensable to ascertain whether the overall passage has a different but equally meaningful reading when the other acceptation is considered. If the new interpretation is meaningless, then the only solution is to accept the sense of "be alongside"; if, on the other hand, it is indeed meaningful, then the argument according to which these subscriptions allow us to state that the practice of excerpting previous exegetic sources and transcribing them in the margins of the relevant literary text (i.e. thereby producing scholiographic corpora or possibly mere corpuscula) was already being undertaken in Late Antiquity cannot be regarded as conclusive. But Guglielmo Cavallo does not seem to appreciate this aspect when he minimizes the fact that $\pi \alpha \rho \alpha \dot{\alpha} \varepsilon \tau \alpha \iota$ may not involve any reference to the position on the page, and states that the distribution of the exegetic complex in the margins must have been evident when actually viewing the manuscript, as in a sort of philologie $d u$

15 This is clearly explained by Cavallo in Cavallo/Del Corso 2012, 57: “... mi sembra che il fenomeno (scil. of scholiography in the Late Antique age) si possa verificare - in mancanza di un qualche testimone tardoantico, sicuro e indiscusso, direttamente conservatosi - mediante un esemplare omerico di data più tarda (scil. Venetus A)" ("it seems to me that the phenomenon [scil. of scholiography in the Late Antique age] can be verified - in the absence of any certain and incontestable Late Antique witness - by means of a Homeric exemplar of a later date [scil. Venetus A]"). Cf. also Cavallo/Del Corso 2012, 61.

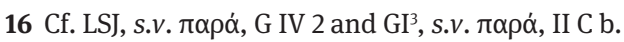

17 Montana 2010 and Montana, this volume, with discussion of the passages and with the previous bibliography. 
regard ${ }^{18}$. This is true for us, who read the subscriptions in a codex with scholia such as Venetus A, but in order to remain true to the rigorous line of argument mentioned above, we should not unquestioningly accept the assumption that when these subscriptions were written for the first time, in Late Antiquity, they were designed as an accompaniment to precisely this same type of product: for in this manner the argument become circular, in the sense that we end up presupposing what we intended to demonstrate.

Is it therefore possible that the short annotations in question may effectively have been composed in the Late Antique age, but that they point to a rather different type of activity as compared to the selection and redactional organization of exegetic material of various types in the margins of the codex?

Let us start by recalling a few basic aspects concerning the overall ancient exegetic tradition relating to the Iliad and, more specifically, the tradition that has come down to us through Venetus A. The modern editor of the scholia vetera maiora, Hartmut Erbse ${ }^{19}$, argued that this mass of materials was conglutinated and arranged alongside the Homeric text no earlier than the Byzantine age ${ }^{20}$. The materials were described as composed mainly on the basis of two ancient elements: on the one hand the works of the four authors mentioned in the subscriptions of Venetus A, presumably gathered together in a single book, traditionally known as the Viermännerkommentar $(\mathrm{VMK})^{21}$; and on the other, the scholia exegetica, a conglomeration of notes designed to provide clarification of the Homeric text, on all levels ${ }^{22}$. The progenitor of this composite array can be identified as a compilation (c) derived mainly from three commentaries that go back to the imperial age, and dated to the Byzantine age by Erbse $^{23}$. To these should be added the $D$-scholia, excluded from Erbse's edition, which were transmitted mostly independently, without the Homeric text, and are composed of glosses and a set of

18 Cavallo/Del Corso 2012, 60.

19 Erbse used the expression scholia maiora (or the alternative form, scholia grammatica) to refer to the specific object of his edition, from which he excluded the class that was traditionally identified as scholia minora, namely the scholia D (Erbse 1969, XI), on which see here infra.

20 Erbse 1969, XI-XIII.

21 The term has now become widely used, even though Erbse himself (1969, XII) defined it as a "verbum haud satis memorabile".

22 Erbse 1969, XII-XIII.

23 Erbse 1969, XLVIII-LII. One of the hypomnematic sources conjectured by Erbse to stand behind $\mathrm{c}$ is well reflected in the recently published commentary P.Oxy. 76.5095, dating from the $\mathrm{V}^{\text {th }} /$ $\mathrm{VI}^{\text {th }}$ or the $\mathrm{VI}^{\text {th }} / \mathrm{VII}^{\text {th }}$ century CE (ed.pr.: Montanari 2012; studies on the relation to the scholia exegetica: Montanari 2009a; Montana 2013; on dating: Porro, this volume). 
mythographic explanations (Mythographus Homericus), zetemata (problems), aporiai/lyseis (difficulties/solutions).

In Erbse's hypothesis, there was a Late Antique stage of compilation in hypomnematic form, from which the scholiographic arrangement would not develop until a later stage: “... a scribis doctis aetatis demum Byzantinae varii loci ex illis libris quattuor virorum [scil. the Viermännerkommentar] aliisque hypomnematibus antiquis electi in ea genera distributi sunt, quae in codicibus nostris apparent" ${ }^{24}$. Erbse reiterated this same conviction even when he became acquainted with the first study by Nigel Wilson on the overall subject of scholiography, which argued for a Late Antique origin of the phenomenon ${ }^{25}$. The editor of the Iliadic scholia declared he was willing to espouse Wilson's vision, but only on condition that the formation of the corpus of scholia to the Iliad was excluded from consideration; on this latter issue, Erbse maintained his position unwaveringly (and even Wilson conceded it was an exceptional case) ${ }^{26}$. With regard to the subscriptions of Venetus A, Erbse - who did not consider them as Late Antique but rather not "multo vetustiores ... quam exemplum Veneti A"27, explained

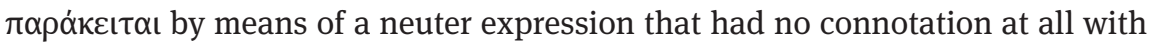
regard to a position in the margins. In his view, the text of the colophons was to be taken as declaring that "scholia composita esse e commentariis quattuor grammaticorum, Didymi dico, Aristonici, Nicanoris, Herodiani”28. It is perfectly plausible, also on the basis of this scholar's view concerning the formation of the corpus of Iliadic scholia, that Erbse's translation was designed - albeit implicitly - to forestall and correct just such a "spontaneous" version that would interpret the Greek in the sense of "be placed alongside".

As compared to the exegetic traditions that can be recognized in the corpus of scholia to Homer briefly mentioned above, the material contained in the margins of Venetus A has a manifold nature; it includes not only extracts from VMK but also material traceable to the scholia exegetica and the $D$-scholia, as well as excerpta from a series of other writings, above all of a lexicographic nature, such

\section{Erbse 1969, XIII.}

25 Wilson 1967.

26 Erbse 1971, 547 (“Cui [scil. Wilson's theory] animo prompto paratoque assentiar, dummodo liceat scholia in Iliadem excipere; nam haec nono demum saeculo conglutinata esse inveniuntur, ita quidem in marginibus librorum aetatis Photianae exarata et disposita, ut ex hypomnematibus veteribus profecta esse, non e scholiis marginalibus pendere videantur"). As mentioned, Wilson himself $(1967,247)$ allowed, for the Iliad, the formation of the scholiastic corpus in the Middle Byzantine age.

27 Erbse 1975, 571; cf. Erbse 1969, XLVII.

28 Erbse 1969, XV (my italics). 
as those of Apollonius the Sophist, Porphyry, Orion, Orus, Methodius, Choeroboscus, the Epimerisms ${ }^{29}$. The only one of these components to be mentioned in the subscriptions is the first one, the so-called Viermännerkommentar. Nothing more is known about this work of compilation of the four philological-grammatical treatises than the information supplied in the colophons of Venetus A, and it is not clear when, and by whom, it was done. According to Lehrs, whose point of view was followed by Ludwich, a period dated too long after the life of Herodian cannot be taken into consideration, and van der Valk has indicated that he is in favor of a dating within the IV ${ }^{\text {th }}$ century, an opinion recently shared by Dickey, whereas Erbse went as far as extreme Late Antiquity ( $\mathrm{V}^{\text {th }}-\mathrm{VI}^{\text {th }}$ century $)^{30}$. The editor of the scholia also hypothesized he could recognize the conglomerate

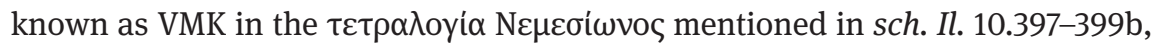
explaining in the Praefatio: “... fortasse vir doctus quidam vel amator carminum Homericorum nomine Nemesion quinto fere vel sexto p. Chr. n. saeculo commotus est, ut illos quattuor libros inter se coniungeret" ${ }^{31}$. However, just a few years later, in the apparatus ad loc., he admitted the ambiguity of the text of the scholium and put forward an alternative hypothesis, suggesting that the tetralogy of Nemesion could be a further commentary which, he conjectured, the epitomizer perhaps utilized in addition to the works of the four grammarians ${ }^{32}$. In effect, it has been shown that the most reasonable position is to maintain the tetralogy (whatever this title is taken to mean) of Nemesion separate from the undertaking we call VMK, recognizing that the apparently evocative nature of the name $\tau \varepsilon \tau \rho \alpha \lambda$ oyí $\alpha$ is pure coincidence ${ }^{33}$.

On the other hand, what can be stated with a fair degree of confidence is that at a certain point of Late Antiquity an initial compilation was undertaken, which merged information deriving from the four works, respectively of Aristonicus, Didymus, Herodian and Nicanor. According to Ludwich, the formulation of the subscriptions seems to suggest that the first two works were excerpted more systematically, and that a more discriminating selection was made for the other

29 Erbse 1969, XLIV-XLVIII; cf. Erbse 1960, 78-122.

30 Lehrs 188233 , 31-32; Ludwich 1884-1885, 1.78-82; van der Valk 1963-1964, 1.107; Dickey 2007, 19; Erbse 1969, XLV-XLVIII.

31 Erbse 1969, XLVII.

32 Erbse 1973, 85-86 (“ad haec verba explicanda Oedipo, ut dicunt, opus coniectore est”).

33 Nickau 1977, 260-263; thus already in Ludwich 1884-1885, 1.80 n. 106; cf. Pontani 2005, 97 n. 211, Filoni 2007, 203-206 and Mazzucchi 2012, 447. Cavallo 1992, 102-103 (=2002, 185), on the other hand, is open to the possibility of the identification of Nemesion with the compiler of VMK. An isolated position is that of van Thiel 2000a, 11-12 (cf. van Thiel 2014, 1.27-28), who has cast doubt on the very existence of VMK. 


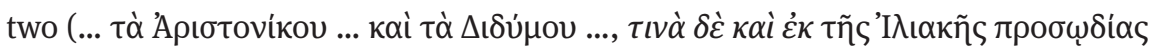

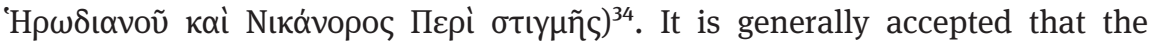
product of this operation, VMK, still had a hypomnematic form, i.e. was independent from the text of the poem. In comparison to such a stage, the scholiastic apparatus of Venetus A is the result of considerable alterations: its original core has not only been amplified by the addition of extraneous elements, as has been noted $^{35}$, but it has also undergone reductions and rearrangements. In Ludwich's view, this would account for the fact that in the scholia one no longer perceives a difference of treatment - which he hypothesized in VMK - distinguishing the works of Aristonicus and Didymus from those of Herodian and Nicanor.

What kind of, and how many, phases were necessary to achieve the transition from VMK to the situation found in Venetus A, in which the far more heterogeneous mass of annotations is found alongside the Homeric text, remains an open question. It is commonly believed that the intermediary closest to Venetus A is a lost codex, generally referred to as $\mathrm{ApH}$, from the names Apion and Herodorus which Eustathius repeatedly quotes to indicate his sources of VMK material ${ }^{36}$. The figures to whom these names refer are completely unknown to us, and we can form no more than a very vague impression of them; however, one may plausibly

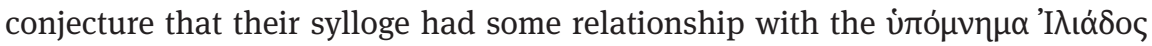
which is mentioned more than once as a source in the Etymologicum Genuinum ${ }^{37}$. Another hypothesis, less widely shared, is that the allusions to a great undertaking of restoration and renewal, including graphic renewal, of ancient and ruined texts of Homer, which Cometas (IX ${ }^{\text {th }}$ century), in several epigrams, boasts of having carried out personally, could have been referring precisely to the accomplishment of this compilation ${ }^{38}$. In van der Valk's view, the ApH utilized by Eus-

34 Ludwich 1884-1885, 1.79 n. 105.

35 Cf. also Ludwich 1884-1885, 1.79 and n. 105; Erbse 1969, XV ("facile autem lector cognoscit his fragmentis [scil. VMK's] scholia aliarum familiarum et explicationes adventicii generis addita esse").

36 Erbse 1969, XLV-XLVII. Cf. the objection of Nagy 2004, 6-7 n. 15, which invokes the "comparative evidence" discussed by Haslam 1978, 71: nevertheless Haslam's article simply takes into consideration the subscription in ms. Firenze, Biblioteca Medicea Laurenziana, Plut. 32.9 of

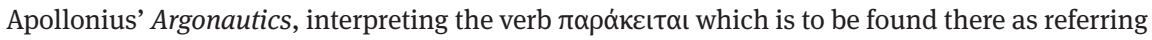
to marginal annotation.

37 Erbse 1960, 128-131; Alpers 1991, 252-257; Pontani 2005, 148; Mazzucchi 2012, 441-442.

38 AP 15.36, 37, 38, 40. The idea comes from Alpers 1991, 252-257 (cf. also Alpers 2013, 69-72, according to whom this work is likely to have been a source on which John of Sardis drew for the commentary on Aphthonius); see also Pontani 2005, 143 (with additional bibliography in n. 297), 148, who believes that Alpers' theory is not implausible, and Mazzucchi 2012, 442 n. 143, who, on the contrary, believes it is poorly founded. 
tathius was indeed related to Venetus A, but it should more properly be regarded as a descendant of a common antecedent, which he called $\mathrm{VMK}^{2}$; the latter, he believed, did have VMK as its base form, but adapted to the tastes of the Byzantine era thanks to an amplification achieved by means of the exegetical and the $D$-scholia, as well as by making use of other sources ${ }^{39}$. The format of ApH - still a separate commentary or already arranged "like a frame" around the poetic text is another controversial point, although the idea of an exegetic apparatus positioned in the margin is often regarded as certain ${ }^{40}$. The way in which Eustathius speaks of this work would seem to suggest something more in the nature of an autonomous text, according to a recent hypothesis put forward by Carlo Maria Mazzucchi, who also believes that Apion and Herodorus operated in a Christian Neoplatonic school of Alexandria at the time of John Philoponus, which would place ApH in the VI ${ }^{\text {th }}$ century. Accordingly, in Mazzucchi's vision this work, thus containing a commentary structured by lemmas, was one of the two antigraphs that the copyist of Venetus A used to create his own Iliadic codex with scholia ${ }^{41}$.

We have now reached the final transitional stage - likewise shrouded in uncertainty - of this prolonged chain of transmission: namely, the stage of what stood immediately upstream of Venetus A. Was whoever drew up the Venice codex copying an identical exemplar, with the mass of exegetic material already "framing" the text, or was it precisely on that occasion that the heterogeneous materials were blended together and arranged around the text of Homer? And in the latter case, what sources were used, and in what form, to create this product? Some scholars have argued that the precision in distribution of the exegetic material in relation to the text and the careful balance of the result displayed by Venetus A indicate that it must be a copy of an antigraph with the same mise en page $^{42}$. In particular, each of its pages contains 25 lines of the Homeric text (with rare exceptions) $)^{43}$ and all the associated annotations are skilfully positioned, without carrying over from one page to another, often presented in two blocks, one in the upper margin and the other by the side of the line to which the first

39 Van der Valk 1963-1964, 1.1-28 for ApH, 29-69 for VMK².

40 Cf. Pontani 2005, 143, 148; this opinion is also shared by van der Valk 1963-1964, 1.25-28; Alpers 1991, 253-254 (who invokes, as his main argument, the fact that Et.Gen. uses the expression $\sigma \chi 0$ $\lambda$ เov $\pi \alpha \rho \alpha \kappa \varepsilon i \mu \varepsilon v o v$, but on the meaning of this expression see the discussion in Montana 2010, 185-192, and both Ercoles and Montana, this volume); contra Erbse 1953, $23-24$.

41 Mazzucchi 2012, 442-447.

42 Cf. e.g. West 2001a, 140; Cavallo/Del Corso 2012, 60-61, following in the footsteps of Maniaci 2006.

43 West 2001a, 140. Naturally, when the transition from one book to another occurs within a page, the number of lines on the page decreases: Mazzucchi 2012, 437 n. 115. 
scholium of the group in question refers, as well as a series of shorter intermarginal and interlinear notes ${ }^{44}$. But when the amount of annotations is such as to occupy the entire writing area, the exegetic text extends to reach down precisely to the end of the last line without contractions or expansions of the writing. In the sporadic cases of an excess of material the overflow is organized as a column in the external margin but there may, also, be additions in the lower margin, or alternatively the entire scholiastic apparatus of the whole page is written in a smaller module ${ }^{45}$. However, the same characteristics of balance and precision in organizing the scholiastic material have also been interpreted in the opposite direction. Thus in Mazzucchi's view, such a result could be obtained only by virtue of a project based on advance knowledge both of the space that would be taken up by the writing and also of the type and frequency of the abbreviations used by the individual and particular copyist who was to be entrusted with the task: only once this variable had been fixed would it be possible to calculate the most suitable number of Iliadic lines per page and the material dimension of the sheet, so that the latter could also host the associated exegesis, which would likewise have had to be known in advance. A text planned in this manner was therefore destined to a specific hand, and if it had been reproduced at a later date by a different hand, this would probably have led to displacement and problems in managing the available space ${ }^{46}$. A further objection put forward by Mazzucchi is that anyone who hesitates to believe that such a well calibrated arrangement as the corpus of scholia of Venetus A can have been constituted for the first time at the very moment when the codex in question was written - i.e. directly as a "fair copy" - must presuppose an antigraph in which this operation was performed, and this merely shifts the problem to the antigraph. However, I feel that scholars who subscribe to this hypothesis of reconstruction are suggesting that organization of the mass of exegetic material in the presumed model was not so successful as that displayed by its apograph, which may well have used the model as a sort of rough draft on the basis of which the scribe then created his own, perfected, arrangement of the material.

44 On this type of scholia, cf. infra, in the text and below, n. 48.

45 I am referring to the description given by Mazzucchi 2012, 436 (cf. also Erbse 1969, XIV; West 2001a, 140; Blackwell/Dué 2009, 6-7; Hecquet 2009). The entire manuscript is visible in high resolution digital photographs published under a Creative Commons License, at the web address www.homermultitext.org: the history of the project, performed under the guidance of the Center for Hellenic Studies of Harvard University, is recounted by Blackwell/Dué 2009, 14-18 (cf. Ebbott 2009, 52-55); prior to this recent accomplishment, scholars could make use of the printed facsimile published in 1901 by Domenico Comparetti (Blackwell/Dué 2009, 13-14; Ebbott 2009, 50-52). 46 Mazzucchi 2012, 436-437. 
Mazzucchi believes that the copyist who put together Venetus A - but the same could also be said of an antigraph of Venetus A, for those who do not admit the possibility of an impeccable creation at the first attempt - had two sources in front of him, as mentioned above: 1) a manuscript with the text of the Iliad, with accents, punctuation marks and some indications of vowel quantity, accompanied by critical signs, paragraphoi, short scholia in the margins and in the interlinear spaces, and equipped with the subscriptions containing the $\pi \alpha \rho \alpha \dot{\kappa \varepsilon \iota \tau \alpha \iota ~ f o r-~}$ mulation; in Mazzucchi's vision, this codex may originally have been composed in majuscule in the Late Antique age and then have been transliterated in the IX ${ }^{\text {th }}$ $\mathrm{X}^{\text {th }}$ century, or it may have already been in minuscule from the very start, though Mazzucchi prefers the first hypothesis; 2) a manuscript in minuscule containing the commentary, structured into lemmas, in which the copyist of Venetus A (or whoever was directing the editorial project) delimited sections pertaining to 25 Iliadic lines at a time. According to this line of interpretation, this second source was the so-called commentary of Apion and Herodorus ${ }^{47}$, and it formed the basis of the main body of the scholia of Venetus A - those that Erbse labels as "A". All the rest of the material contained in the Venice manuscript, i.e. the text of the Iliad, the critical signs, the short interlinear and intermarginal scholia $\left(\mathrm{A}^{\mathrm{il}}, \mathrm{A}^{\mathrm{im}}\right.$, $\mathrm{A}^{\text {int }}$ of Erbse $)^{48}$, is thus assumed to derive from the first codex. It should be pointed out that in conjecturing a manufact of this kind, Mazzucchi is hypothesizing a witness of scholiography stricto sensu - notes in the margins, the outcome of compilation from different sources (inasmuch as he presumes that subscriptions pertaining to the "four men" are present in the manufact in question) -, but when he discusses its possible dating ${ }^{49}$, mentioned here above, he does not highlight the connection between this dating and the problem of the birth of scholiography.

This hypothesis of reconstruction, as outlined here, has a bearing on the delicate problem of the relation between the "major" scholia and those that Erbse calls "Textscholien". The latter, referred to collectively as $\mathrm{A}^{\mathrm{t}}$, and formed of the groups known as $\mathrm{A}^{\mathrm{im}}$ and $\mathrm{A}^{\mathrm{int}}$, are the short notes set in the free space beside the text, respectively between the text and the block of "major" scholia and between the text and the binding. There is no agreement on whether the A scholia and the

47 Mazzucchi 2012, 437, 447-448.

48 Erbse 1969, XIV (cf. C): $A^{\text {il }}$ indicates short scholia written above the Iliadic line, partly extracted from the "major" scholia and partly from explanations dependent on $D$-scholia, $\mathrm{A}^{\text {im }}$ short scholia jotted between the Homeric text and the "major" scholia (that is to say, A), $\mathrm{A}^{\text {int }}$ short scholia written in the internal margin. On the other hand, $\mathrm{A}^{\mathrm{ext}}$ designates explanations, taken mainly from the scholia exegetica, penned by a more recent hand in the margin that is external to the A-scholia.

49 Mazzucchi 2012, 437 n. 113. 
$\mathrm{A}^{\mathrm{t}}$ scholia should be considered to derive from the work of distinct scholars - with the $\mathrm{A}^{\mathrm{t}}$ group written before the $\mathrm{A}$ group, although those in the $\mathrm{A}^{\mathrm{t}}$ set sometimes refer the reader to the scholia in the A set - or whether they go back to a single redactor $^{50}$. But the main problem is that the two groups show no appreciable differences in the provenance of their content, both of them presenting an intermingling of VMK and extraneous material ${ }^{51}$. If the genesis of the $\mathrm{A}^{\mathrm{t}}$ scholia were to be traced to an exemplar in which the $\mathrm{A}^{\mathrm{t}}$ group constituted the entire scholiastic corpus, described by the subscriptions as composed of excerpta from Aristonicus, Didymus, Herodian and Nicanor, then a predominance of genuinely VMK scholia would be expected in this group. But this is not the case. One has the impression that Mazzucchi's choice concerning which one of the two presumed models that were utilised to draw up Venetus A could have contained the subscriptions is influenced by the traditional view, according to which the subscriptions mean that the excerpta of the "four men" "lie in the margins": since the other antigraph that he hypothesizes (ApH) is presumed to be in the form of a commentary, it is probably excluded ipso facto.

On the other hand, among those who argue that Venetus A is a copy of a model whose mise en page was already arranged in the form of a frame, Guglielmo Cavallo dates this structural characteristic back as far as the Late Antique phase. He hypothesizes that a Homeric codex of Late Antiquity, large-sized and with broad margins, equipped with an exegetic apparatus (essentially traceable back to VMK) that was placed beside the text, formed the basis for a learned operation in the Middle Byzantine age, when it was copied, with the addition of further exegetic material, into another codex, which acted as an intermediate link between the first manuscript and Venetus $\mathrm{A}^{52}$. Cavallo takes into consideration the possible interposition of a discrete composite commentary between the ancient hypomnemata and the marginal form, but he nevertheless restricts the transition towards the latter to the Late Antique age $\mathrm{e}^{53}$. This limitation is linked

50 The former position was put forward by Erbse 1969, XIV, who adduced f. 46r as an example supporting the sequence of events he hypothesized (cf. already Erbse 1953, 34 and 37 and Erbse 1960, 127-128), whereas the latter view was held by van der Valk 1963-1964, 1.42, 70-76. The suggestion of different redactors was also proposed by Ludwich 1884-1885, 1.98-102.

51 Cf. van der Valk 1963-1964, especially 1.72.

52 Cavallo/Del Corso 2012, 59-61.

53 Cavallo 1992, 102 (2002, 184-185): "In tal caso il trasferimento di questo materiale in margine al testo omerico va riferito ad un momento successivo, ma pur sempre da collocare nella tarda antichità" ("In this case, the transfer of this material into the margin of the Homeric text should be regarded as having taken place at a later time, though still within the time frame of Late Antiquity"). 
partly to the assumption that no commentary transmitted independently of the poetic text survived up to such a late period as the IX ${ }^{\text {th }}$ century, and also to the argument that if manufacts of this kind had effectively come down to Byzantine erudition, care would have been taken in the Byzantine age to transcribe them or in any case to preserve them and transmit them to future generations $\mathrm{s}^{54}$. On the other hand, it could be objected that these learned figures, in the spirit of eranizein that characterized their era, might have reutilized these commentaries, transferring their contents into the margins of the manuscripts that carried the respective literary works, with the aim of preserving, as exhaustively as possible and in an organic manner, the wisdom handed down from the earlier centuries. Once this operation had been completed, the hypomnemata utilized could well have been lost, inasmuch as they may no longer have been copied independently precisely because they had already been included in the compilations of the scholiographic corpora.

To conclude this general overview, let us return to the initial query and attempt to test whether, in the traditional framework thus reconstructed, the acceptation of $\pi \alpha \rho \alpha \dot{\kappa} \varepsilon ı \alpha \alpha$ as "is in the margins" is the only one that makes the iterated subscription of Venetus A meaningful. In the other possible interpretation of the verb, as was stated earlier, the meaning would be "is quoted / cited / extracted". Applying it to the texts in question, the phrase would declare: "[Hereby] are excerpted the works On signs, of Aristonicus; On the diorthosis of Aristarchus, of Didymus; some parts of the Prosody of the Iliad, of Herodian; On Punctuation, of Nicanor". Such a statement would thus record a selection and fusion of materials from the four works without necessarily declaring in what format the operation had been carried out. In this case, it could adapt perfectly to the compilation to which these writings were subjected, in a phase that was still relatively close to the originals: this compilation may have been carried out in the form of an independent commentary still on rolls, i.e. a roll for each commentary on an individual book of the Iliad, or already on codex but in a phase that was chronologically still close enough to the practice of rolls as to reflect their customs. This would fit well with the Late Antique allure of the subscriptions on the exegetic sources, which was mentioned at the beginning, and with their repetition for each book of the poem. We can imagine successive phases - we do not know for certain which and how many phases - through which this amalgam became further blended with other material, and underwent a selection, ending up, in its final stage, arranged as a frame in the margins of Venetus A. During this protracted chain of transmission, it may have carried along with it the label of

54 Cavallo/Del Corso 2012, 59-60. 
its origin, i.e. the subscriptions documenting the ancient auctoritates to whom the "noble" (Alexandrian-Aristarchean) core of the exegetic texts can ultimately be traced back. And the very authoritativeness and the erudite hallmark they bestowed on the product provide a good justification of why they survived and were relayed over the centuries during the numerous transitional steps. Once the

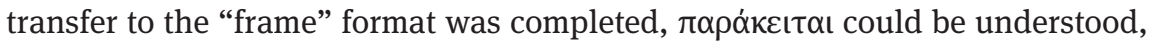
from the Byzantines onward (and similarly by us modern scholars), in the sense of "is in the margin", precisely by virtue of the philologie du regard invoked by Cavallo $^{55}$. This was a statement which, at that point, was indeed true but not exhaustive, since, as already pointed out, the scholiastic corpus of Venetus A contains far more than that which is declared by the subscriptions. This too is an element that fits with the conjecture that the subscriptions were originally formulated to account for a different situation. Thus the colophons of Venetus A could represent the survival of a pre-existing formal element which took on a different significance when it became part of the new "frame" structure. In conclusion, given that the subscriptions of Venetus A might actually not refer at all to the positioning of the exegetic annotations in the margins of the manuscript containing the literary text to which reference is made, they prove not to be conclusive for dating the origins of scholiography.

55 Cf. supra, n. 18. 